IKONOMIKA: Journal of Islamic Economics and Business

Volume 2, No 2 (2017)

ISSN: 2527-3434 (PRINT) - ISSN: 2527-5I43 (ONLINE)

Page: $177-200$

\title{
Peran Bank Pembiayaan Rakyat Syariah dalam Mengimplementasikan Keuangan Inklusif Melalui Pembiayaan UMKM
}

\author{
Achmad Rifa'i \\ Fakultas Ekonomika dan Bisnis, Universitas Gadjah Mada \\ achmadrifaiI86@gmail.com
}

\begin{abstract}
The empowerment of MSMEs can be one of the answers to state not only economic growth but also new money-cycle centers. Financial Inclusion is carried out to address these issues through the deepening of financial access to the regions especially towards the lower middle class. The Syariah Financing Bank as an extension of the formal financial institution seeks to become an intermediary institution in implementing an financial inclusion that aims to state access to finance in Indonesia. This study aimed to see the role of Sharia Financing Bank performed its duty in financing UMKM as an effort to achieve financial inclusion. The data used was secondary data. The research methodology used was descriptive with qualitative approach. Qualitative data analysis used Open Coding, Axial Coding and Selective Coding analysis techniques. Based on the results of the study using three financial inclusion indicators of Bank Indonesia, which are access, usage, and quality indicated that Shariah Financing Bank has so far managed to maintain and increase its capacity to provide access, channel financing, and financial ratios.
\end{abstract}

Keywords: Sharia Financing Bank, Financial Inclusion, MSMEs

\begin{abstract}
Abstrak
Pemberdayaan UMKM bisa menjadi salah satu jawaban untuk memeratakan tidak hanya pertumbuhan ekonomi tetapi juga pusat-pusat perputaran uang yang baru. Keuangan inklusif diusung untuk menjawab permasalah tersebut melalui pendalaman akses keuangan ke daerah-daerah terutama terhadap masyarakat menengah bawah. Bank Pembiayaan Rakyat Syariah selaku perpanjangan tangan lembaga keuangan formal berusaha untuk menjadi intermediatory institution dalam mengimplementasikan keuangan inklusif yang bertujuan untuk memeratakan akses keuangan di Indonesia. Penelitian ini bertujuan untuk melihat peran Bank Pembiayaan Rakyat Syariah melakukan tugasnya dalam pembiayaan UMKM sebagai upaya untuk mencapai keuangan inklusif. Adapun data yang digunakan adalah data sekunder. Metodologi penelitian yang digunakan adalah deskriptif dengan pendekatan kualitatif. Analisis data kualitatif yang digunakan menggunakan teknik analisis Open Coding, Axial Coding dan Selective Coding. Berdasarkan hasil penelitian menggunakan tiga indikator keuangan inklusif Bank Indonesia yaitu access, usage, dan qualitymenunjukkan bahwa Bank Pembiayaan Rakyat Syariah sejauh ini telah berhasil menjaga dan meningkatkan kapasitasnya dalam memberikan akses, menyalurkan pembiayaan, dan rasio keuangan.
\end{abstract}

Kata kunci: Bank Pembiayaan Rakyat Syariah, Keuangan Inklusif, UMKM

Received :juli 20, 20I7- Revised: September 07, 20I7- Accepted: Oktober 26, 2017

Fakultas Ekonomika dan Bisnis, Universitas Gadjah Mada

achmadrifai186@gmail.com

DOI: I0.24042/febi.v2iI.943I77I77 


\section{A. PENDAHULUAN}

\section{Latar Belakang}

Indonesia merupakan salah satu negara yang diprediksi beberapa tahun mendatang akan menjadi bagian dari 5 besar negara dengan nilai GDP yang tertinggi pada tahun 2030. Melihat potensi besar itu, merupakan sebuah harapan tersendiri bagi pemerintah maumpun masyarakat yang ingin melihat Indonesia sejajar dengan negara-negara besar lainnya. Besarnya nilai GDP akan sangat mendongkrak perekonomian yang artinya perputaran barang dan jasa sangat tinggi sehingga akan mampu menggerakkan sendi-sendi perekonomian dengan lebih besar. Meskipun demikian, besarnya nilai GDP tidak selalu diikuti pemerataan yang baik pada setiap lapisan ekonomi di masyarakat. Hal ini terlihat jelas ketika melihat disparitas yang terjadi di lapangan dimana masyarakat yang berpenghasilan tinggi memiliki rumah mewah dan tinggal di kota besar sedangkan masyarakat yang berpenghasilan rendah harus rela untuk tinggal di rumah sederhana atau perumahan kelas menengah yang berlokasi di pinggiran kota. Belum lagi jika melihat ketimpangan perekonomian yang terjadi antara di kota dan desa yang signifikan. Wajar jika banyak anak muda yang merantau dari desa ke kota untuk mencari kehidupan yang lebih baik karena minimnya pergerakan ekonomi yang ada di pedesaan dibandingkan dengan di kota besar.

Lapangan pekerjaan menjadi masalah klasik yang tiada berujung ketika membahas ketimpangan yang ada di Indonesia. Hal ini sangat mendasar karena banyak masyarakat yang lebih memilih untuk mencari lapangan pekerjaan dibanding menciptakan lapangan kerja itu sendiri. Bekerja di perusahaan besar secara psikologis menciptakan rasa bangga dan nyaman. Usaha Mikro Kecil dan Menengah atau yang lebih sering disebut UMKM merupakan salah implemetasi untuk menciptakan lapangan pekerjaan dimana peran UMKM lebih solid dan tahan terhadap guncangan eksternal tidak seperti perusahaan ataupun industri besar yang rentan ketika terjadi gejolak perekonomian di luar negeri yang dapat smempengeruhi kinerja perusahaan. Selain itu, berdasarkan data Badan Pusat Statistik 2010 - 20I4, peran UMKM lebih baik dalam penyerapan tenaga kerja dibandingkan dengan industri besar. 
Tabel I

Grafik Jumlah Tenaga Kerja UMKM dan Industri Besar

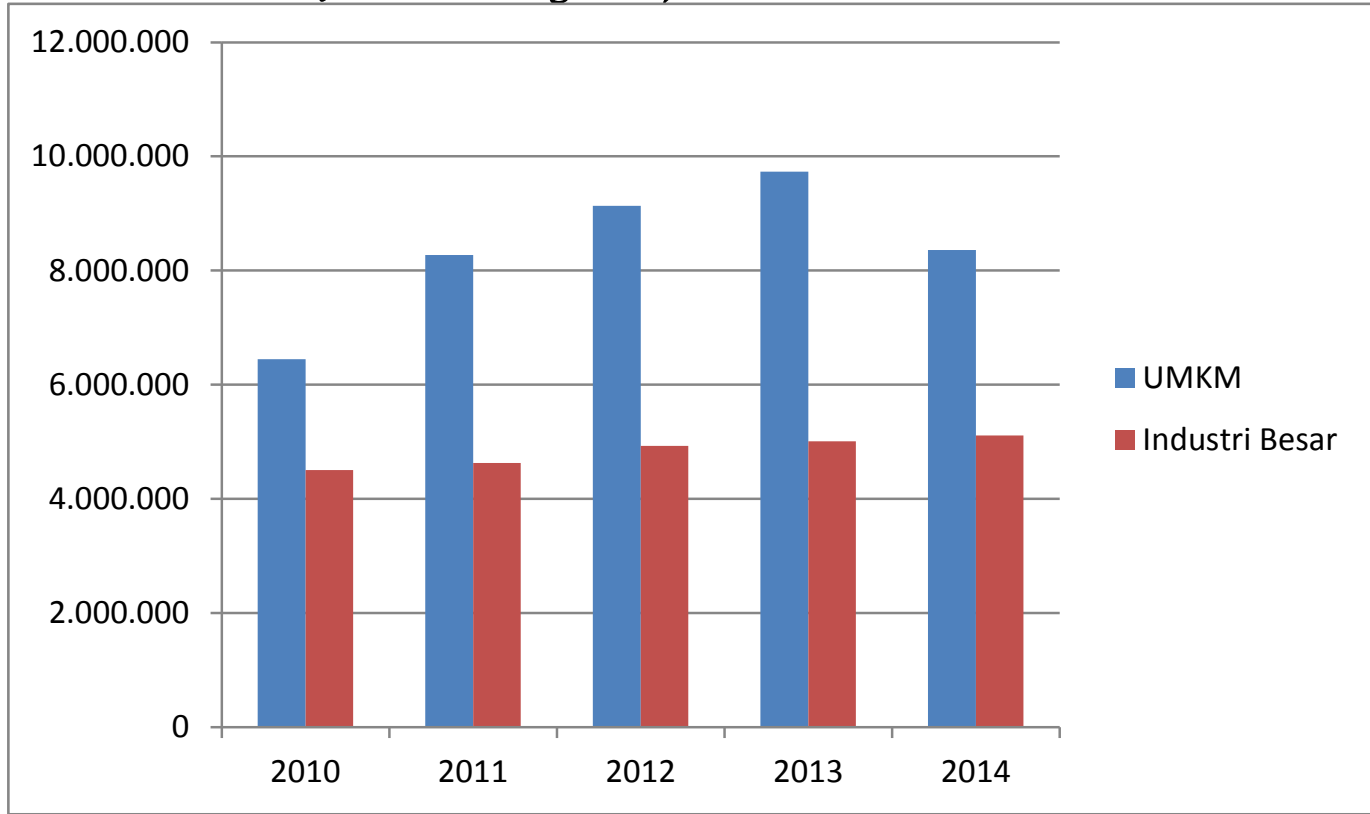

Sumber: Badan Pusat Statistik (diolah)

Dari grafik di atas, terlihat jelas bahwa UMKM memiliki kemampuan meyerap tenaga kerja lebih baik dibandingkan industri besar. Secara berturut-turut pada tahun 2010 - 20I4, UMKM mampu menyerap tenaga kerja sebanyak 6.447.260, 8.274.635, 9.131.288, 9.734.III, dan 8.362.746 sedangkan industri besar pada tahun rentang waktu yang sama mampu menyerap tenaga kerja 4.50I.I45, 4.629.369, 4.928.839, 5.004.9I2, dan 5.I08.53I.

UMKM memiliki implikasi yang cukup luas ketika mampu dimaksimalkan keberadaanya. Tidak hanya akan mampu menyerap tenaga kerja lebih banyak dibanding industri besar tetapi juga mampu menjadi salah untuk alat untuk mengentaskan kemiskinan. Meskipun volume perputaran barang dan jasa serta rupiah pada industri besar lebih tinggi dibanding UMKM, kenyataanya terjadi ketidakadilan dalam proses bagi hasil karena tentu pemilik industri besar akan memiliki porsi lebih banyak ketika mengalami keuntungan sebaliknya ketika mengalami kerugian akan berakibat pada pengurangan tenaga kerja. Sedangkan UMKM mampu lebih mandiri menjalankan kegiatan usahanya baik ketika mengalami keuntungan maupun kerugian. UMKM juga merupakan salah satu sektor usaha yang tahan terhadap gejolak ekonomi seperti krisis ekonomi global 2008. Selain itu, UMKM mampu menjadi salah alat pemberdayaan masyarakat 
terutama di pedesaan untuk mengoptimalkan hasil buminya. Tidak hanya langsung dijual secara mentah tetapi harus diolah untuk menambah nilai tambahnya yang kemudian diperjual-belikan melalui UMKM. Tentu jenis UMKM pun menyeseuaikan dengan potensi dan keadaan sekitarnya. Yang terpenting adalah UMKM harus menjadi sektor usaha yang mampu memberikan terobosan dalam inovasi, produk, dan pemasarannya karena pada dasarnya hampir sektor usaha di Indonesia berjenis UMKM. Menurut Badan Pusat Statistik pada tahun 2015 terdapat 3.668.873 UMKM dengan kontribusi terhadap PDB mencapai 57,84\%.

Walaupum UMKM menempati fondasi perekonomian yang cukup sentral tetapi pada kenyataannya akses terhadap permodalan masih belum maksimal. Ini dikarenakan usaha yang dijalankan UMKM lebih bersifat mandiri tanpa memiliki grup atau dibawah grup lain seperti industri besar. Kebanyakan produksinya adalah dalam bentuk barang yang masih menggunakan teknologi rendah. Karena bercirikan perekonomian daerah, maka mempengaruhi juga orientasi pasar UMKM yang cenderung lokal. Melihat kelemahan UMKM, tentu hal ini yang membuatnya terkadang sulit untuk mengakses permodalan dariinstitusi keuangan formal karena latar usahanya yang bisa dikategorikan unbankable atau juga disebut kelompok usaha defisit. Dengan keadaan yang seperti itu, sangat dibutuhkan bantuan dari pihak lain berupa keuangan, manajemen, dan teknologi untuk membangun UMKM yang tangguh. Tetapi ada salah hal yang unik dari ciri UMKM dimana kepedulian dan komitmennya terhadap moralitas. Di saat para pengusaha dan industri besar banyak melakukan kejahatan bisnis yang melanggar hukum seperti mengemplang pajak, UMKM tetap berpegang teguh pada etika bisnis dan moralitas.

Keterbatasan sumber pembiayaan yang dihadapi UMKM terutama dari lembaga keuangan formal seperti perbankan, pegadaian, maupun leasing menyebabkan UMKM cenderung bergantung dari pembiayaan informal. Bentuknya seperti pelepas uang (rentenir) yang kemudian biasanya berkembang menjadi koperasi simpan-pinjam yang membebankan bunga cukup tinggi sebagai konsekuensi mudahnya mendapatkan pinjaman. Dalam perkembangannya, lembaga-lembaga informal ini lebih diminati dikalangan pelaku UMKM karena sifatnya yang fleksibel seperti syarat peminjaman dan jumlah pinjaman yang tidak seketat lembaga formal dan proses pencairannya yang juga cepat. Hal ini merupakan salah satu indikator bahwa model pembiayaan yang cepat, mudah, dan tidak ketat dalam hal persyaratan dimana ini disediakan oleh lembaga informal merupakan strategi yang sesuai untuk menumbuhkan minat pelaku usaha yang membutuhkan pembiayaan pada skala yang relatif kecil dan sedang. Tetapi tentu 
saja lembaga informal ini membebankan konsekuensi yang cukup berat bagi keberlangsungan UMKM akibat penerapan bunga yang cenderung tinggi. Kondisi ini mengakibatkan ketidakberdayaan UMKM ketika menjalankan usahanya terutama ketika kondisi sedang lesu atau merugi sehingga menyebabkan berjatuhannya UMKM yang kemudian akan kembali meningkatkan pengangguran yang akhirnya menghambat program pengentasan kemiskinan yang dicanangkan pemerintah.

Masih sulitnya akses permodalan yang menyentuh sampai lapisan UMKM tentu tidak sejalan dengan konsep keuangan inklusif yang sedang digalakan pemerintah melalui Bank Indonesia maupun Otoritas Jasa Keuangan. Pada dasarnya, menurut Bank Indonesia, kebijakan keuangan inklusif adalah suatu bentuk pendalaman layanan (financial deepening service) yang ditujukan kepada masyarakat in the bottom pyramid untuk memanfaatkan produk dan jasa keuangan formal seperti sarana menyimpan uang yang aman, transfer, menabung, maupun pinjaman dan asuransi. Hal ini dilakukan tidak saja menyediakan produk dengan cara sesuai tetapi dikombinasikan dengan berbagai aspek. Konsep keuangan inklusif mulai diperkenalkan pada tahun 2010 dimana ternyata pada level perekonomian mikro yang ada di masyarakat tidak terlalu terdampak ketika terjadinya krisis. Melihat minimnya dampak krisis pada tingkat mikro, keuangan inklusif diupayakan hadir untuk mendorong perekonomian level bawah seperti UMKM untuk mampu ikut berkontribusi terhadap perekonomian nasional. Bagaimanapun juga, menurut World Bank pada tahun 20I4, financial inclusion index Indonesia hanya tercatat sebesar 36\%. Indeks ini berarti bahwa masih ada $64 \%$ penduduk berusia $>$ I5 tahun yang belum mampu mengakses lembaga keuangan formal baik untuk menabung maupun untuk memperoleh pembiayaan. Sedangakan lebih spesifik pada sektor perbankan syariah hanya mampu diakses sebesar 4,6\% dari total pangsa pasar nasional (Ernst and Young, 2013), setara dengan hanya melayani kurang dari I\% populasi Indonesia.

Keuangan inklusif yang saat ini menjadi fokus pemerintah melalui BI dan OJK harus didukung secara penuh karena pada dasarnya sangat sesuai dengan konsep agama islam yang hadir untuk mengangkat derajat kalangan menengah bawah. Perbankan syariah memiliki peran sentral untuk ikut serta meningkatkan indeks keuangan inklusif melalui pembiayaan terhadap UMKM maupun masyarakat yang tidak tersentuh institusi keuangan formal. Peran perbankan syariah pun mulai tampak menggeliat sejak beberapa tahun terakhir terutama setelah disahkannya Undang-Undang Nomor 2I Tahun 2008 Tentang Perbankan Syariah.Tercatat data OJK pada April 20I7, jumlah jaringan kantor Bank Umum 
Syariah (BUS) berjumlah I.84I, Unit Usaha Syariah (UUS) berjumlah 336, dan Bank Pembiayaan Rakyat Syariah (BPRS) berjumlah 285. Jumlah jaringan kantor yang ada saat ini cukup mengalami peningkatan yang signifikan jika dibandingkan dengan sebelum terbitnya UU Tentang Perbankan Syariah. Seperti yang dicatat jugaoleh OJK pada Desember 2007, dimana berturut-turut jumlah jaringan kantor BUS, UUS, dan BPRS sebanyak 422, I95, dan II4. Hal ini tentu menunjukkan bahwa pemerintah serius untuk melibatkan perbankan syariah yang mengangkat konsep rahmatinlil alamin untuk ikut terlibat secara serius meningkatkan masyarakat kelas bawah maupun UMKM untuk mengakses institusi keuangan formal. Berdasarkan pemaparan data, fakta, dan fenomena yang ada,penulis tertarik untuk meneliti lebih lanjut keikutsertaan perbankan syariah dalam mengimplementasikan keuangan inklusif melalui pembiayaan syariah terhadap UMKM sebagai salah satu sasaran utama pedalaman layanan institusi keuangan formal.

\section{B. LITERATUR REVIEW}

\section{Usaha Mikro, Kecil, dan Menengah}

Berdasarkan UU No. 20 Tahun 2008 tentang Usaha Mikro, Kecil, dan Menengah bahwa usaha mikro adalah usaha produktif milik orang perorangan dan/atau badan usaha perorangan yang memenuhi kriteria usaha mikro yaitu modalnya maksimal 50 juta, sedangkan omsetnya mencapai 300 juta. Usaha kecil adalah usaha ekonomi poduktif yang berdiri sendiri, yang dilakukan oleh orang perorangan atau badan usaha yang bukan merupakan anak perusahaan atau bukan cabang perusahaan yang dimiliki, dikuasai, atau menjadi bagian baik langsung maupun tidak langsung dari usaha menengah atau usaha besar yang memenuhi kriteria modal maksimal 500 juta dengan omset maksimal 2,5 milyar. Usaha menengah adalah usaha ekonomi produktif yang berdiri sendiri, yang dilakukan oleh orang perseorangan atau badan usaha yang bukan merupakan anak perusahaan atau cabang perusahaan yang dimiliki, dikuasai, atau menjadi bagian langsung maupun tidak langsung dengan usaha kecil atau usaha besar dengan jumlah kekayaan bersih maksimal sebesar I0 milyar atau hasil penjualan tahunan sebesar 50 milyar. Pengelompokan atau kategorisasi usaha-usaha di suatu negara mempunyai tujuan strategis, antara lain dikaitkan dengan standar kuantitatif tertentu serta seberapa jauh dapat dimasukkan ke dalam jenis-jenis usaha atau bisnis (Partomo dan Soejodono, 2004). Tujuan pengelompokan usaha dapat disebutkan beragam dan pada intinya mencakup empat macam tujuan sebagai berikut, a) untuk 
keperluan analisis yang dikaitkan dengan ilmu pengetahuan, b) untuk keperluan penentuan kebijakan-kebijakan pemerintah, c) untuk meyakinkan pemilik modal atau pengusaha tentang posisi perusahaannya, dan d) untuk mempertimbangkan badan tertentu berkaitan dengan kinerja perusahaan.

Madanchian et al (2015) dalam penelitiannya mengemukan bahwa peran UMKM di Malaysia telah mendapatkan perhatian akibat dari kesadaran masyarakat dan pemerintah terhadap kontribusi UMKM pada perekonomian. Sumber daya dan keterampilan yang baik perlu ditingkatkan dan dilatih untuk membuat performa UMKM di Malaysia menjadi lebih baik yang kemudian akan membuatnya kompetitif di pasar negara maju maupun negara berkembang.UMKM juga menjalan peran yang krusial di negara lain seperti peneltian yang dilakukan oleh Anwar Ali Shah et al (20I2) mengungkapkan bahwa sektor UMKM di Pakistan merupakan sektor terbesar terhadap perekonomian negara yang selanjutnya mampu memberikan kontribusi melalui penyerapan tenaga kerja di dalam negeri, mengurangi angka pengangguran, dan menyediakan kesempatan kerja yang lebih besar terutama di daerah pedesaan. Oleh karena itu, UMKM, pemerintah yang memegang wewenang dan perbankan perlu untuk memastikan bahwa UMKM mampu untuk melakukan ekspansi dan mengembangkan skala usahanya yang mana kemudian akan memberikan peran penting terhadap perkembangan sosial ekonomi masyarakat. Hidayat Keskin et al (2010) dalam penelitiannya memaparkan hal yang sejalan dengan hasil penelitian-penelitian sebelumnya dimana peran UMKM memiliki peran penting dalam hal menumbuhkan perekonomian secara bersama-sama di negara maju dan negara berkembang meskipun terdapat perbedaan dalam hal definisi UMKM di antara berbagai macam organisasi dan negara. Sekarang, dibanding industri yang berskala besar, UMKM telah mampu mengambil peran dalam mengembangkan perekonomian menjadi lebih baik melalui penggunaan modal kerja yang tidak banyak tetapi menyerap banyak tenaga kerja dan tidak memiliki struktur manajemen yang rumit sehingga menurunkan biaya produksi. Singkatnya, konsep small is beautiful menjadi penting pada situasi ekonomi sekarang ini dibandingkan industri besar. Sejalan dengan diusahakannya peran keuangan inklusif untuk mengangkat perekonomian pada level mikro, Bank Indonesia mengeluar peraturan nomor I4/22/PBI/20I2 yang memuat beberapa poin yang pada intinya adalah kewajiban bank-bank untuk menyalurkan dananya dalam bentuk kredit atau pembiayaan kepada UMKM dengan pangsa pasar minimal 20\% secara bertahap yang diikuti dengan insentif dan disinsentif. Perluasan bentuk bantuan teknis 
dilaksanakan dalam bentuk penelitian, pelatihan, penyediaan informasi, dan fasilitas.

Para pelaku UMKM sangat berpotensi dalam mengembangkan usahanya dengan resiko kerugian kecil dan kesadaran untuk membayar cukup baik melalui pembinaan-pembinaan dan dengan konsep kekeluargaan yang profesional. Kondisi tersebut mencerminkan bahwa adanya potensi pemberian bantuan pembiayaan ke UMKM. Hal ini bertujuan dalam rangka penyebaran resiko perbankan, sementara suku bunga kredit UMKM sesuai dengan tingkat bunga pasar sehingga bank akan mempunyai margin yang cukup. Sektor ini memiliki ketahanan yang relatif lebih baik dibandingkan dengan usaha besar karena kurangnya ketergantungan pada bahan baku impor dan potensi pasar yang tinggi mengingat harga produk yang dihasilkan relatif rendah sehingga terjangkau oleh golongan ekonomi lemah. Bagaimanapun juga, ini tetap harus mendapat dukungan baik perbankan sebagai penyokong dana maupun masyarakat Indonesia untuk lebih mencintai produk dalam negeri.

\section{Pembiayaan Lembaga Keuangan Syariah}

Lembaga keuangan syariah menjalankan kegiatan usahanya dengan berpedoman pada Al-Quran dan dan Al-Hadits sedangkan landasan filosofisnya berpegang pada falsafah ekonomi syariah yang memiliki satu tujuan, tiga pilar, dan empat pondasi (Suryomurti, 20II). Satu tujuan tersebut yaitu tercapainya kesuksesan yang hakiki dalam berekonomi berupa tercapainya kesejahteraan yang mencakup kebahagiaan (spiritual) dan kemakmuran (material). Tiga pilarnya meliputi a) aktivitas ekonomi yang berkeadilan dengan menghindari eksploitasi berlebihan, spekulatif, dan kesewang-wenangan, b) adanya keseimbangan aktivitas di sektor riil-finansial, pengelolaan risk return, aktivitas bisnis-sosial, aspek spiritual, material dan azas manfaat, kelestarian lingkungan, c) orientasi pada kemaslahatan kehidupan beragama, proses regenerasi, serta perlindungan keselamatan jiwa, harta dan akal. Sedangkan empat podasinya adalah a) meletakkan tata hubungan bisnis dalam koteks kebersamaan universal untuk mencapai kesuksesan bersama, b) kaidah-kaidah hukum muamalah di bidang ekonomi yang membimbing aktivitas ekonomi sehingga selalu sesuai syariah, c) akhlak yang membimbing aktivitas ekonomi senantiasa mengedepankan kebaikan sebagai cara mencapai tujuan, d) Ketuhanan Yang Maha Esa yang menimbulkan kesadaran bahwa setiap aktivitas mansuai memiliki akuntabilitas ketuhanan sehingga menumbuhkan integritas yang sejalan dengan prinsip good coporate governance dan market discipline. 
Tujuan pemerintah mendirikan bank syariah tidak hanya untuk memberikan alternatif perbankan non-riba bagi masyarakat, tetapi juga untuk mengembangkan sektor riil. Hal ini sejalan dengan penjelasan mengenai bank syariah yang merupakan lembaga keuangan yang berfungsi memperlancar mekanisme pada sektor riil melalui kegiatan usahanya dalam hal ini pembiayaan mudharabah yang berdasarkan prinsip syariah (Isretno, 20I I). Adapun pembiayaan-pembiayaan yang dimiliki oleh bank syariah bermacam-macam. Mulai dari pembiayaan berbasis bagi hasil seperti yang disebutkan sebelumnya yaitu mudharabah dan musyarakah, pembiayaan berbasis jual beli murabahah hingga pembiayaan yang bersifat sosial/kebajikan qardh. Model pembiayaan mudharabah memiliki arti akad antara dua pihak yang mengharuskan salah satu dari keduanya untuk menyerahkan sejumlah uang kepada yang lain untuk diperdagangkan dengan ketentuan keuntungannya dibagi sesuai dengan kesepakatan antara keduanya (Sabiq, 2009). Lalu mengenai musyarakah, Sabiq juga menjelaskan bahwa model pembiayaan ini adalah berupa akad kerjasama antara dua orang yang bersekutu dalam modal dan keuntungan. Kemudian akad jual beli atau murabahah memiliki arti suatu akad jual beli barang dengan menyatakan harga perolehan dan keuntungan yang disepakati oleh penjual dan pembeli (Karim, 20II). Selanjtunya adalah akad qardh yaitu pinjaman kebajikan/lunak tanpa imbalan dan biasanya untuk pembelian barangbarang fungible atau barang yang dapat diperkirakan dan diganti sesuai berat, ukuran, dan jumlahnya (Ascarya, 20II).

Bank Pembiayaan Rakyat Syariah (BPRS) merupakan salah satu perpanjangan tangan dari lembaga keuangan syariah yang memiliki core kegiatan usaha pada pendanaan dan pembiayaan kepada sektor-sektor riil untuk mengangkat perekonomian masyarakat. Berdasarkan UU No. 2I Tahun 2008 pasal I tetang ketentuan umum menyebutkan bahwa pengertian BPRS adalah bank syariah yang dalam kegiatannya tidak memberikan jasa dalam lalu lintas pembayaran. Selanjutnya pada pasal 2 dijelaskan bahwa perbankan syariah dalam melakukan kegiatan usahanya berasakan prinsip syariah, demokrasi ekonomi, dan prinsip kehatia-hatian. Sedangkan pengertian pembiayaan disini adalah pendanaan yang diberikan suatu pihak kepada pihak lain untuk mendukung investasi yang telah direncanakan, baik dilakukan sendiri maupun lembaga. Dengan kata lain, pembiayaan adalah pendanaan yang dikeluarkan untuk mendukung investasi yang telah direncanakan. Menurut Ismal (2013) menyatakan bahwa perbankan syariah di Indonesia ada bagian dari institusi keuangan yang telah mampu menyediaan pelayanan peminjaman dan pembiayaan mereka sendiri dan tentu saja dengan berlandaska prinsip dan nilai islam. Meskipun perbankan syariah dibatasi untuk 
melakukan kegiatan usahanya seperti bank konvensional karena berlandaskan agama islam yang melarang praktik riba, kontirbusi dari perbankan syariah sebagai intermediator keuangan menuju pembangunan ekonomi Indonesia yang berkelanjutan tetap menujukkan tren yang positif sejauh ini.

\section{Keuangan Inklusif}

Pada KTT Pittsburgh bulan September 2009. Para pemimpin G-20 berkomitmen untuk meningkatkan akses pelayanan keuangan kepada masyarakat. Kemudian diluncurkanlah G20 Financial Inclusion Experts Group sekaligus juga disepakatinya model Small Medium Sized Enterprise(UMKM) untuk mendapatkan akses pembiayaan dari perbankan serta memperkuat regulasi keuangan inklusif dan perlindungan konsumen. Pada KTT Toronto bulan Juni 2010, para pemimpin G-20 menghimbau sektor swasta untuk ikut andil dalam mewujudkan keuangan inklusif. Hasil kesepakatan dalam KTT G-20 menetapkan keuangan inklusif sebagai pilar penting dalam pembangunan ekonomi dan pengentasan kemiskinan di negara-negara anggotanya. Negara yang memiliki masalah kemiskinan berupaya untuk menciptakan sistem keuangan inklusif. Hal ini menjadikan keuangan inklusif seabagai salah satu fokus pembangunan pada sektor keuangan di berbagai negara, karena sistem keuangan yang baik adalah yang mampu mendorong pertumbuhan ekonomi sekaligus mengurangi kemiskinan.

Keuangan inklusif mempromosikan penghematan dan mengembangkan budaya menabung, meningkatkan akses kredit, baik kewirausahaan maupun konsumsi dan juga memungkinkan mekanisme pembayaran yang efisien sehingga memperkuat basis sumber daya lembaga keuangan yang mampu memberikan manfaat ekonomi sebagai sumber daya dan tersedianya mekanisme pembayaran yang efisien dan alokatif. Bukti empiris menunjukkan bahwa negara-negara dengan populasi penduduk yang besar tetapi belum mempunyai akses yang luas terhadap sektor formal lembaga keuangan, menunjukkan rasio kemiskinan dan ketimpangan yang lebih tinggi. Dengan demikian, keuangan inklusif saat ini bukanlah merupakan pilihan tetapi menjadi sebuah keharusan dan perbankan merupakan pendorong utama untuk mengimplentasikannya (Chakrobarty, 20II). Menurut DemigrucKunt et al (2014) dalam penelitiannya menunjukkan bahwa orang muslim lebih mungkin memiliki akun resmi di perbankan dibandingkan dengan non-muslim. Dengan adanya instrumen-instrumen redistributif dalam ekonomi islam seperti zakat, infaq, shadaqah, maka orang muslim berpotensi besar dalam melakukan keuangan inklusif. 
Kesenjangan terkait keuangan mikro syariah dan instrumen redistribusi tradisional terjadi pada negara-negara yang tergabung dalam Organisasi Kerjasama Islam (OKI). Penelitian menyimpulkanbahwa pengimplementasian instrumen ekonomi konvensional dapat menyebabkan kemiskinan dan ketidakmerataan ekonomi negara-negara muslim. Oleh karena itu, para pembuat kebijakan yang serius dalam mengimplementasikan keuangan inklusif harus memanfaatkan potensi instrumen syariah untuk mencapai tujuan dan fokus pada peningkatan infrastruktur serta dukungan regulasi yang kuat. Instrumen syariah yang dimaksud adalah instrumen redistributif seperti zakat, shadaqah, wakaf, infaq dan qard al-hasan (Mohieldin et al, 2012). Melalui instrumen redistributif tersebut diharapkan akan mampu dalam meningkatkan akses pembiayaan terhadap UMKM maupun masyarakat. Seperti yang ditemukan oleh Leon and Weill (20I7) dalam penelitiannya menunjukkan bahwa perbankan syariah tidak menghadapi masalah dalam menyalurkan pembiayaan sedangkan perbankan konvensional menghadapi beberapa rintangan untuk melalukan pembiayaan. Bagaimanapun juga, perkembangan perbankan syariah memberikan dampak positif terhadap pembiayaan ketika perbankan konvesional kurang memberikan dampak.

Konsep keuangan inklusif baru diluncurkan oleh Bank Indonesia melalui program National Strategy for Financial Inclusion pada tahun 2010 sebagai upaya untuk memperluas akses masyarakat terhadap jasa keuangan. Selama ini, 32\% atau 76 juta penduduk sama sekali belum tersentuh institusi keuangan foral. Selain itu, $60 \%-70 \%$ UMKM juga belum memiliki akses terhadap perbankan. Padahal hampir 53 juta masyarakat miskin yang bekerja di sektor UMKM memiliki potensi yang sangat besar untuk menurunkan pengangguran dan mengurangi kemiskinan. Implementasi keuangan inklusif di Indonesia sudah dilakukan dalam berbagai bentuk seperti pemberian Kredit Usaha Rakyat (KUR) dan pengembangan Baitul Mal wa Al Tanwil (BMT). KUR adalah skema kredit usaha khusus bagi UMKM dan koperasi yang telah memenuhi standar kelayakan usaha tetapi belum memiliki agunan sesuai dengan persyaratan yang ditetapkan oleh perbankan. Melalui program KUR ini, pemerintah berupaya meningkatkan akses UMKM kepada kredit usaha dari perbankan dengan cara meingkatkan kapasitas perusahaan penjamin. Perbankan syariah pun sangat diharapkan mampu untuk terlibat lebih 
mendalam untuk ikut dalam skema pemberian pembiayaan kepada UMKM melalui berbagai produk-produknya sesuai akad dan masuk secara langsung ke sektor riil.

\section{METODOLOGI PENELITIAN}

Pada penelitian ini, metodologi yang digunakan adalahdeskriptif dengan pendekatan kualitatif. Adapun objek penelitian adalah Bank Pembiayaan Syariah di Indonesia yang sumber datanya diperoleh dari website Otoritas Jasa Keuangan. Dengan demikian, jenis data adalah data sekunder yang umumnya berupa bukti, catatan, atau laporan historis yang telah tersusun rapi dalam arsip (data dokumenter), baik yang dipublikasikan maupun tidak dipublikasikan (Moeloeng, 2004). Teknik yang digunakan untuk mengumpulkan data dalam penulisan ini adalah: I) Studi literatur, yaitu serangkaian kegiatan yang berkenaan dengan metode pengumpulan data pustaka, membaca, dan mencatat serta mengolah bahan penelitian, 2) Dokumenter, yaitu membaca dan menelaah dokumentasi seperti laporan-laporan penulisan sebelumnya serta artikel yang diakses dari internet, buku, maupun jurnal yang sesuai dengan permasalahan. Pada metode ini, penulis hanya memindahkan data yang relevan dari suatu sumber atau atau dokumen yang diperlukan. 3) Diskusi yaitu cara pengumpulan data dengan melakukan pembicaraan dan pertukaran pikiran dengan orang-orang yang berkompeten dengan objek yang sedang diteliti untuk memecahkan permasalahan yang ditemukan. 4) Intuitif-Subjektif, yaitu merupakan keterlibatan penulis atas permasalahan yang sedang dibahas. Analisis data kualitatif yang digunakan menggunakan teknik analisis yang dikembangkan oleh Strauss dan Corbin (2007) dengan tiga langkah besar, yaitu I) Open Coding yang merupakan prosedur merinci kelengkapan datam memeriksa, menjelaskan konsep lokal, dan mengkategorikan data. 2) Axial Coding yang didalamnya terdapat model grounded theory, yaitu kondisi penyebab $>$ fenomena $>$ konteks $>$ kondisi pendukung dan penghambat $>$ strategi interaksi dan tindakan $>$ konsekuensi. 3) Selective Coding yaitu menghasilkan simpulan yang kemudian diangkat menjadi general design. Adapun indikator keuangan inklusif yang digunakan dalam penelitian ini adalah sesuai dengan yang ditetapkan oleh Bank Indonesia. Indeks Keuangan Inklusif (IKI) adalah salah satu cara alternatif untuk pengukuran keuangan inklusif yang menggunakan indeks multidimensional berdasarkan data makroekonomi terutama pada jangkauan layanan sektor perbankan. Pengukuran IKI pada dasarnya merupakan upaya yang dilakukan Bank Indonesia untuk mengkombinasikan berbagai indikator sektor perbankan sehingga pada akhirnya IKI dapat menggabungkan beberapa informasi 
mengenai berbagai dimensi dari sebuah sistem keuangan yang inklusif yaitu I) akses, 2) penggunaan, dan 3) kualitas. Indikator yang digunakan Bank Indonesia tidak berbeda jauh dari indikator utama keuangan inklusif yang digunakan oleh Demirguc-Kunt et al (20I2) dalam penelitiannya. I) formal accountyaitu kepemilikian akun pada lembaga keuangan formal, 2) formal saving yaitu kebiasaan menabung masyarakat pada institusi keuangan formal, dan 3) formal credit yaitu persepsi dalam mempertimbangkan penggunaan kredit bank.Dalam penelitian ini sendiri, penulis akan mencoba membangun konsep keuangan inklusif melalui pembiayaan UMKM sebagai salah satu strategi percepatan pencapaian indikator keuangan inklusif di Indonesia.

\section{HASIL DAN PEMBAHASAN}

\section{Akses Bank Pembiayaan Rakyat Syariah di Indonesia Terhadap UMKM}

Sesuai Indikator Keuangan Inklusif yang dibuat oleh Bank Indonesia, akses merupakan salah satu indikator yang sangat penting dari keberadaan perbankan. Akses yang dimaksud tentu saja adalah kemampuan bank untuk menjangkau masyarakat dalam mengakses lembaga keuangan formal baik dalam hal menabung maupun untuk memperoleh pembiayaan. BPRS yang notabene core kegiatan usahanya memberikan bantuan pembiayaan harus menjadi ujung tombak utama dalam mengimplementasikan akses terhadap masyarakat dan UMKM. Terutama kepada para kelompok usaha yang sedang membutuhkan bantuan modal untuk meningkatkan kapasistas usahanya dalam hal produksi yang kemudian akan berimplikasi pada penyerapan tenaga kerja yang lebih banyak. Peran BPRS tidak hanya sebatas pada pembiayaan kepada UMKM sebagai target utama penggerak perekonomian mikro dan menengah tetapi juga pada pendampingan dan pengelolaan dana yang ada sehingga akan membuat keuangan UMKM menjadi lebih accountable, credible, transparant,dan managable yang artinya antara kedua belah pihak yaitu UMKM sebagai penerima dana dan BPRS sebagai penyandang dana akan memperoleh manfaat pembagian hasil yang lebih maksimal.

Dalam melakukan pembiayaan terhadap usaha-usaha yang memerlukan tambahan modal, tentu BPRS pun membutuhkan dana tidak hanya dari pemilik modal tetapi juga tabungan masyarakat. Oleh karena itu, menghimpun dan menyalurkan dana merupakan dua sisi yang sangat lekat dalam dunia perbankan. BPRS pun demikian, bedanya adalah dalam menghimpun dana dari masyarakat digunakan akad-akad yang sesuai muamalah sehingga terjadi mutual benefit antara nasabah yang menabung dengan pihak BPRS yang menyimpan dana yang kemudian nantinya akan dikelola dalam berbagai bentuk termasuk untuk melakukan 
Peran Bank Pembiayaan Rakyat Syariah dalam Mengimplementasikan Keuangan Inklusif Melalui Pembiayaan UMKM

(Achmad Rifa'i)

pembiayaan kepada UMKM yang notabene merupakan bagian usaha yang banyak dijalankan masyarakat.

Tabel 2

Perkembangan Pembiayaan UMKM dan Dana Pihak Ketiga

Bank Pembiayaan Syariah di Indonesia ${ }^{*}$

\begin{tabular}{rllllll}
\hline $\begin{array}{c}\text { Keteranga } \\
\mathbf{n}\end{array}$ & 20II & 20I2 & 20I3 & 20I4 & 20I5 & 20I6 \\
\hline Pembiayaa & I.547.20 & 2.080 .09 & 2.620 .26 & 3.005 .85 & 3.377 .98 & 3.570 .60 \\
n UMKM & 5 & 4 & 3 & 8 & 7 & 6 \\
\hline Dana & 2.095 .33 & 2.937 .80 & 3.666 .17 & $4.028 .4 \mathrm{I}$ & 4.801 .88 & 5.823 .96 \\
Pihak & 3 & 2 & 4 & 5 & 8 & 4 \\
Ketiga & & & & & & \\
\hline
\end{tabular}

Sumber: Statistik Perbankan Syariah (diolah) ${ }^{*}$ dalam juta rupiah

Tabel 3

Perkembangan Pembiayaan UMKM dan Dana Pihak Ketiga

Bank Pembiayaan Syariah di Indonesia (dalam grafik)

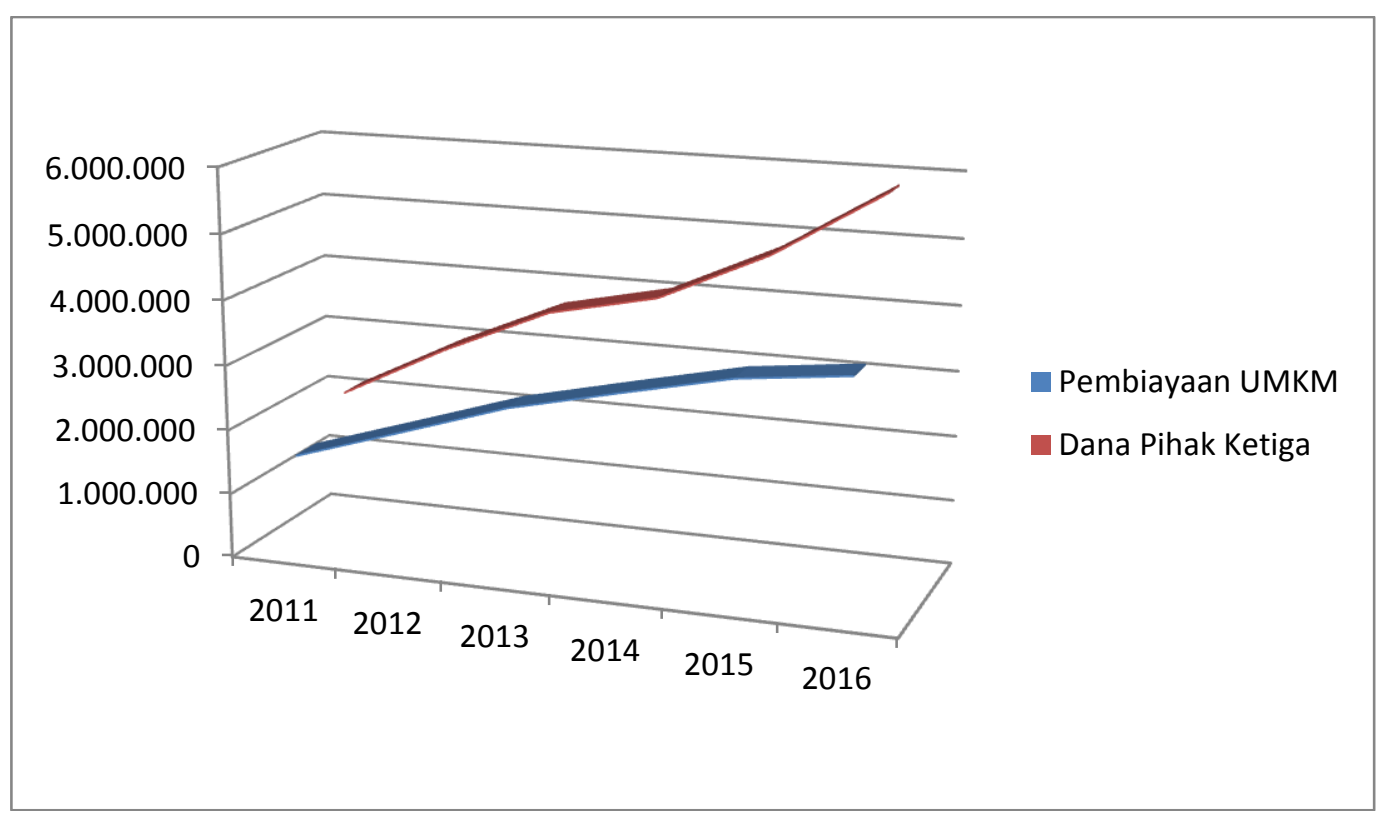


Berdasarkan data dan grafik diatas terlihat bahwa BPRS menerapkan manajamen yang baik antara rasio DPK terhadap pembiayaan khusus bagi UMKM. Ini menjelaskan bahwa BPRS menerapkan prinsipwell prudentdalam melakukan kegiatan pembiayaan terhadap UMKM. Hal ini pun tercermin dari rasio Financing to Depocit Ratio (FDR). Tetapi data yang ada di OJK merupakan rasio FDR dimana DPK dibagi total pembiayaan sedangkan pada penelitian ini penulis berfokus pada pembiayaan pada UMKM saja sesuai dengan tujuan penelitian. Selain baiknya indikator rasio DPK terhadap pembiayaan UMKM, hal lain yang bisa dilihat dari data di atas adalah terus meningkatnya jumlah DPK maupun pembiayaan UMKM dari tahun ke tahun. Hal ini menandakan bahwa masyarakat percaya bahwa BPRS merupakan salah satu lembaga keuangan formal yang mampu menjadi partner dan pihak yang dipercaya dalam setiap transaksi pasif maupun aktif. Dalam transaksi pasif seperti menabung, Ascarya (2007) menjelaskan bahwa menabung di bank syariah bisa menjadi salah satu langkah perencanaa di masa depan. Produk-produk pendanaan bank syariah ditujukan untuk memobilisasi dan investasi tabungan untuk pembangunan perekonomian dengan cara yang adil sehingga keuntungan yang adil dapat terjamin bagi semua pihak. Tujuan mobilisasi dana merupakan hal penting karena islam secara tegas mengutuk penimbunan tabungan dan menuntut penggunaan dana secara produktif dalam rangka mencapai tujuan sosial ekonomi Islam, melainkan dengan prinsip yang sesuai dengan syariat Islam. Sedangkan dalam transaksi aktif seperti pembiayaan UMKM, peran BPRS sangat terlihat dimana setiap tahunnya mengalami peningkata dalam jumlah pembiayaan. Hal ini pun sejalan dengan meningkatnya jumlah UMKM setiap tahunnya di Indonesia. Artinya, pertumbuhan UMKM harus juga diikuti BPRS untuk mampu menjangkau UMKM dalam mengakses produk-produk pembiayaan yang ditawarkan oleh BPRS.

Perbankan syariah dalam hal ini melalui BPRS merupakan layanan perbankan yang dirasa sesuai dengan karakteristik pelaku usaha UMKM. Kesesuaian ini ditinjau dari pelaksanaan prinsip bagi hasil serta adanya pendampingan usaha. Tetapi, untuk membuat perbanakan syariah memberikan dukungan yang maksimal ini, perlu dukungan faktor internal maupun ekternal yang berupa jaminan profitabilitas dan rentabilitas dari sektor UMKM sendiri serta kebijakan-kebijakan yang dibuat pemerintah. Selain dukungan dari pemerintah berupa kebijakan khusus sebagai stimulus pada sektor UMKM. Diperlukan pula peningkatan pengetahuan dan keahlian bankir syariah pada dunia UMKM disemua sektornya, terutama pemahaman preferensi para pelaku usaha dalam pemilihan bank yang dipilihnya sebagai rekanan pembiayaan modal kerjanya. 
Peran Bank Pembiayaan Rakyat Syariah dalam Mengimplementasikan Keuangan Inklusif Melalui Pembiayaan UMKM

(Achmad Rifa'i)

\section{Penggunaan Dana Bank Pembiayaan Rakyat Syariah}

Tujuan penggunaan dana yang digunakan oleh UMKM menjadi aspek yang krusial. Hal ini didasari pada kegiatan apa dana tersebut digunakan. Ketika UMKM menggunakan dana pembiayaan hanya untuk membayar utang karena terlanjur membuat utang di masa lalu, tentu akan sangat tidak maksimal pembiayaan yang diberikan oleh BPRS. Kemudahan akses pembiayaan yang diberikan oleh BPRS seperti yang ditunjukkan data dimana pembiayaan BPRS terhadap UMKM terus meningkat setiap tahunnya harus disikapi dengan bijak. Pembiayaan yang ada tentu ditujukan untuk kegiatan yang produktif seperti membeli bahan baku, membayar gaji karyawan, berinvestasi mesin-mesin baru dan canggih yang nantinya akan meningkatkan kapasitas produksi. Berdasarkan data yang diperoleh dari OJK, penggunaan dana dari BPRS kepada UMKM ditujukan untuk hal-hal yang produktif.

\section{Tabel 4}

Pembiayaan Bank Pembiayaan Rakyat Syariah

Berdasarkan Jenis Penggunaan

\begin{tabular}{|c|c|c|c|c|c|c|}
\hline $\begin{array}{c}\text { Keteranga } \\
\mathrm{n}\end{array}$ & $20 I I$ & 2012 & 2013 & 2014 & 2015 & 2016 \\
\hline Modal & I.470.I0 & I.835.95 & 2.206 .00 & 2.348 .35 & 2.559 .35 & 2.737 .16 \\
\hline Kerja & 7 & 8 & 4 & 0 & 0 & 7 \\
\hline Investasi & 275.727 & 465.062 & 611.992 & 893.432 & $\begin{array}{l}\text { I.108.59 } \\
7\end{array}$ & $\begin{array}{l}\text { I.I25.59 } \\
5\end{array}$ \\
\hline Konsumsi & 930.095 & $\begin{array}{l}\text { I. } 252.49 \\
9\end{array}$ & $\begin{array}{l}\text { I.6I5.49 } \\
7\end{array}$ & $\begin{array}{l}\text { I.763.47 } \\
7\end{array}$ & $\begin{array}{l}2.097 .22 \\
4\end{array}$ & $\begin{array}{l}2.799 .79 \\
4\end{array}$ \\
\hline
\end{tabular}

Sumber: Statistik Perbankan Syariah (diolah)

*dalam juta rupiah 


\section{Tabel 5}

\section{Pembiayaan Bank Pembiayaan Rakyat Syariah}

Berdasarkan Jenis Penggunaan (dalam grafik)

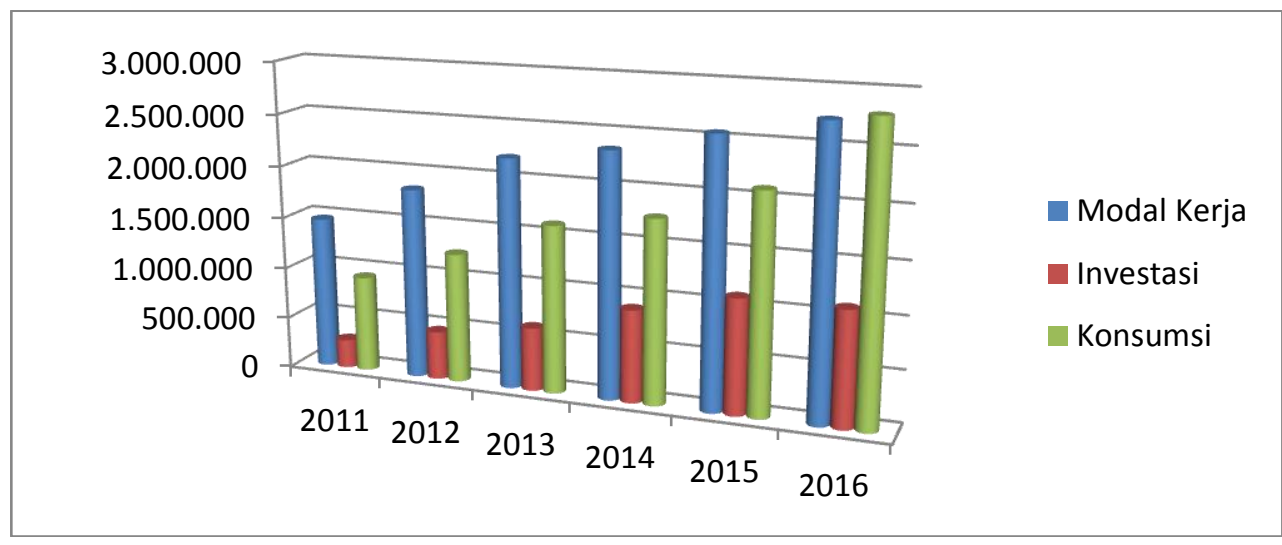

Mengenai indikator kedua ini, BPRS menunjukkan posisinya sebagai lembaga keuangan syariah yang berpihak kepada pembiayaan pada sektor riil. Meskipun pada tahun 2016, jumlah pembiayaan pada sektor konsumsi sedikit melebihi sektor modal kerja, secara keseluruhan dalam enam tahun terakhir BPRS sudah menjadi penyandang dana terhadap sektor pembiayaan yang mampu memberikan efek multiplier secara nyata seperti secara konsisten menjadi sumber pembiayaan bagi UMKM terutama pada sektor modal kerja. Peningkatan modal kerja dari tahun ke tahun tentu mengindikasikan bahwa BPRS merupakan lembaga keuangan yang berfokus pada peningkatan sektor riil sebagai upaya ikut berkontribusi dalam pembangunan ekonomi yang inklusif. Peran perbankan syariah memiliki nilai lebih dalam menggerakkan pertumbuhan ekonomi. Hal ini, karena perbankankan syariah memberikan penekanan kuat pada penghidupan sektor-sektor riil. Penekanan ini sebagai prinsip dasar sistem ekonomi islam yang mengharmonisasikan antara sektor keuangan dengan sektor riil (Dewandru, 2009). Akurasi kebutuhan akan menunjukkan besarnya likuiditas yang dibutuhkan untuk membiayai produksi dan konsumsi yang pada gilirannya menciptakan pertumbuhan ekonomi, penyerapan tenaga kerja, stabilitas harga, dan lain sebagainya.

Penekanan yang kuat pada upaya untuk menghidupkan sektor riil tersebut dapat dilihat dalam pola penghimpunan dan penyaluran dana pada perbankan syariah. Pola penghimpunan dana yang menggunakan akad mudharabah dan wadiah menunjukkan bahwa pengembalian untuk tabungan ataupun deposito nasabah berasal dari pengembangan dana nasabah tersebut pada sektor riil. Demikian pula dengan penyaluran dana dalam akad murabahah, mudharabah, dan 
Peran Bank Pembiayaan Rakyat Syariah dalam Mengimplementasikan Keuangan Inklusif Melalui Pembiayaan UMKM

(Achmad Rifa'i)

musyarakah juga sangat terkait langsung dengan sektor-sektor riil. Dengan demikian, peran perbankan atau institusi keuangan syariah untuk menggerakkan sektor riil sangat besar. Sektor riil yang bergerak menandakan pertumbuhan ekonomi yang pada akhrinya akan menciptakan lapangan pekerjaan, menyerap tenaga kerja, dan mengurangi kemiskinan.

\section{Kualitas Pembiayaan Bank Pembiayaan Rakyat Syariah}

Indikator keuangan inklusif yang terakhir berdasarkan Bank Indonesia adalah kualitas. Dalam penelitian ini, kualitas yang menjadi fokus penelitian adalah kualitasBPRSdalam melakukan pembiayaan. Setiap perbankan harus mengedepankan prinsip kehati-hatian dalam mengelola keuangannya terutama dalam hal pembiayaan. BPRS di Indonesia secara konsisten terus melakukan evaluasi setiap periodenya dalam memberikan pembiayaan terhadap mitranya termasuk UMKM. Prinsip kehati-hatian adalah suatu asas atau prinsip yang menyatakanbahwa bank dalam menjalankan fungsi dan kegiatan usahanya wajib bersikap hati-hati dalam rangka melindungi dana masyarakat yang dipercayakan kepada bank. Hal ini disebutkan dalam pasal 2 UU No. I0 Tahun 1998 sebagai perubahan atas UU Nomor 7 Tahun 1992 Tentang Perbankan, bahwa perbankan Indonesia dalam melakukan usahanya berasaskan demokrasi ekonomi dengan menggunakan prinsip kehati-hatian. BPRS mematuhi prinsip ini dengan mengimplementasikan pembiayaan lebih aktif pada sektor lancar dibanding sektor non lancar.

Tabel 5

Pembiayaan Bank Pembiayaan Rakyat Syariah

Berdasarkan Kualitas Pembiayaan*

\begin{tabular}{|c|c|c|c|c|c|c|}
\hline Keterangan & $20 I I$ & 2012 & 2013 & 2014 & 2015 & 2016 \\
\hline a) Lancar & 2.512 .328 & 4.I45.II9 & 4.610 .238 & 4.610 .238 & 5.292 .330 & 6.087 .260 \\
\hline b) Non Lancar & 163.602 & 218.635 & 288.373 & $394.67 \mathrm{I}$ & $472.84 \mathrm{I}$ & 575.296 \\
\hline $\begin{array}{ll}\text { b.I) } & \text { Kurang } \\
\text { Lancar } & \end{array}$ & 49.319 & 72.806 & 90.581 & I36.25I & $\mathrm{I} 34.5 \mathrm{I} 2$ & I09.24I \\
\hline b.2) Diragukan & 44.663 & 51.649 & 65.847 & 81.069 & 95.060 & 100.645 \\
\hline b.3) Macet & 69.620 & 94.180 & I3I.945 & $\mathrm{I} 77.35 \mathrm{I}$ & 243.269 & 865.409 \\
\hline
\end{tabular}

Sumber: Statistik Perbankan Syariah (diolah)

*dalam juta rupiah 
Dari kualitas pembiayaan yang dilakukan BPRS, terjadi pertumbuhan yang baik dari tahun ke tahun pada sektor lancar. Pertumbuhan ini pun diikuti juga oleh sektor non lancar, namun proporsi terhadap sektor lancar masih sangat jauh sehingga kualitas pembiayaan BPRS termasuk dalam kategori well prudent. Perbankan syariah yang berlandaskan kepada syariat Islam dalam menjalankan kegiatan usahanya mengatur secara lengkap mengenai prinsip muamalah secara umumnya dan perjanjian pada khusunya. Saat ini sebagian dari prinsip tersebut sudah terkonkretisasi dalam beberapa produk bank, baik produk pengerahan dana maupun produk pembiayaan. Produk-produk bank syariah merupakan produk pilihan yang dirancang secara hati-hati yang di dalamnya juga mengandung prinsipprinsip perlindungan bagi nasabahnya. Secara historis, produk-produk tersebut sudah diprakttikkan dalam dunia perniagaan di masa nabi dan sahabat-sahabatnya. Disamping produk utama tersebut, saat ini juga telah muncul beragam produk lain yang dalam pengembangannya diawasi oleh Dewan Pengawas Syariah dari masingmasing bak yang dikendalikan oleh Dewan Syariah Nasional yang dibentuk oleh Majelis Ulama Indonesia.

Selain BPRS mampu terus mengupayakan untuk melakukan peningkatan pada sektor lancar pada pembiayaannya. BPRS di Indonesia juga secara kosnsisten menjaga berbagai jenis rasio yang ada. Hal ini memperkuat bahwa BPRS saat ini sudah sangat profesional dan menerapkan manajemen yang baik dalam menjalankan kegiatan usahanya. Karena dengan tercukupinya berbagai rasio yang ada, menandakan bahwa BPRS merupakan lembaga keuangan yang dikelola dengan baik sehingga akan terus meningkatkan kepercayaan masyarakat terhadap BPRS yang kemudian akan meningkatkan DPK yang pada akhrinya akan menambah modal BPRS yang dikelola dan yang akan disalurkan ke masyarakat maupun UMKM dalam bentuk pembiayaan produktif. Seperti yang tertera dalam tabel dibawah ini terkait rasio keuangan BPRS.

Tabel 6

Rasio Keuangan Bank Pembiayaan Rakyat Syariah*

\begin{tabular}{ccccccc}
\hline Keterangan & $20 \mathrm{II}$ & $20 \mathrm{I2}$ & $20 \mathrm{I3}$ & $20 \mathrm{I4}$ & $20 \mathrm{I5}$ & $20 \mathrm{I6}$ \\
\hline CAR & 23,49 & $25, \mathrm{I} 6$ & 22,08 & 22,77 & $2 \mathrm{I}, 47$ & $2 \mathrm{I}, 73$ \\
& & & & & & \\
\hline ROA & 2,67 & 2,64 & 2,79 & 2,26 & 2,20 & 2,27 \\
& & & & & & \\
\hline ROE & $\mathrm{I} 8,95$ & 20,54 & $2 \mathrm{I}, 22$ & $\mathrm{I} 6, \mathrm{I3}$ & $\mathrm{I} 4,66$ & $\mathrm{I} 6, \mathrm{I} 8$
\end{tabular}


Peran Bank Pembiayaan Rakyat Syariah dalam Mengimplementasikan Keuangan Inklusif Melalui Pembiayaan UMKM

(Achmad Rifa'i)

\begin{tabular}{ccccccc}
\hline NPF & 6, II & 6,15 & 6,50 & 7,89 & 8,20 & 8,63 \\
& & & & & & \\
\hline FDR & I27,7I & I20,96 & I20,93 & I24,24 & I20,06 & I I 4,40 \\
& & & & & & \\
\hline BOPO & $76,3 \mathrm{I}$ & 80,02 & 80,75 & 87,79 & 88,09 & 87,09
\end{tabular}

Sumber: Statistik Perbankan Syariah (diolah)*dalam \%

Secara keseluruhan, dalam enam tahun terakhir BPRS mampu terus secara konsisten menjaga setiap rasio keuangan dalam ambang batasnya masing-masing. Hal ini adalah merupakan implikasi dari penerapan prinsip kehati-hatian yang konsisten pula dalam menjalankan kegiatan usahanya. Meskipun bank syariah dapat bersifat universal banking, bank syariah tetap tidak menghindar dari keharusan memilih segmen tertentu. Pemilihan itu tidak saja ditentukan oleh adanya potensi pasar yang dapat dijangkau tetapi juga dipengaruhi kapasitas masing-masing bank seperti permodalan, sumber daya manusia, sistem dan teknologi dan sebagainya. Bank syariah wajib memiliki sistem organisasi, sistem administrasi dan manajemen yang baik, serta sumber daya insani yang berakhlak, amanah, dan profesional. Jika dibandingkan dengan perbankan konvensional maka bank syariah akan lebih aman dan terjamin kemampuan usahanya karena operasi bank ini dibingkai oleh ketentuan-ketentuan dan prinsip-prinsip syariah. Retriksi syariah sebagai dasar operasionalnya sekaligus merupakan dan menjadi prinsp kehati-hatian bagi bank syariah. Dengan demikian, tujuan diberlakukannya prinsip kehati-hatian tidak lain adalah agar bank selalu dalam keadaan sehat. Dengan kata lain agar selalu liquid dan solvent. Diberlakukannya prinsip kehati-hatian diharapkan agar kepercayaan masyarakat terhadap perbankan tetap tinggi, sehingga masyarakat bersedia dan tidak ragu-ragu menyimpan dananya di bank.

\section{E. REKOMENDASI DAN KESIMPULAN}

Bank Pembiayaan Syariah secara keseluruhan telah menjadi lembaga intermediasi yang secara konsisten dalam mengimplementasikan keuangan inklusif. $\mathrm{Hal}$ ini bisa dilihat dari tiga indikator utama yang ditetapkan Bank Indonesia yaitu akses, penggunaan, dan kualitas. Melihat terus meningkatnya ketiga komponen tersebut, tentu menjadi hal yang menggembirakan bahwa BPRS mampu ikut berkontribusi untuk menjangkau masyarakat menengah bawah yang menjadi sasaran utama keuangan inklusif. Dalam penelitian ini, UMKM diupayakan menjadi salah satu jalan untuk mempercepat strategi pengimplementasian keuangan inklusif di Indonesia, apalagi dilihat melalui data dari OJK bahwa BPRS menaruh porsi lebih besar terkait pembiayaan berdasarkan sektor usaha kepada UMKM dibandingkan kepada sektor usaha yang lain. Hal ini dilakukan BPRS karena meyakini bahwa cara paling efektif dalam melalukan persebaran keuangan inklusif adalah melalui pembiayaan UMKM yang memiliki efek multiplier tinggi. Oleh karena itu, penulis berusaha membangun konsep keuangan inklusif melalu pembiayaan UMKM melalui bagan dibawah ini. 
IKONOMIKA

Volume 2, No 2 (2017)

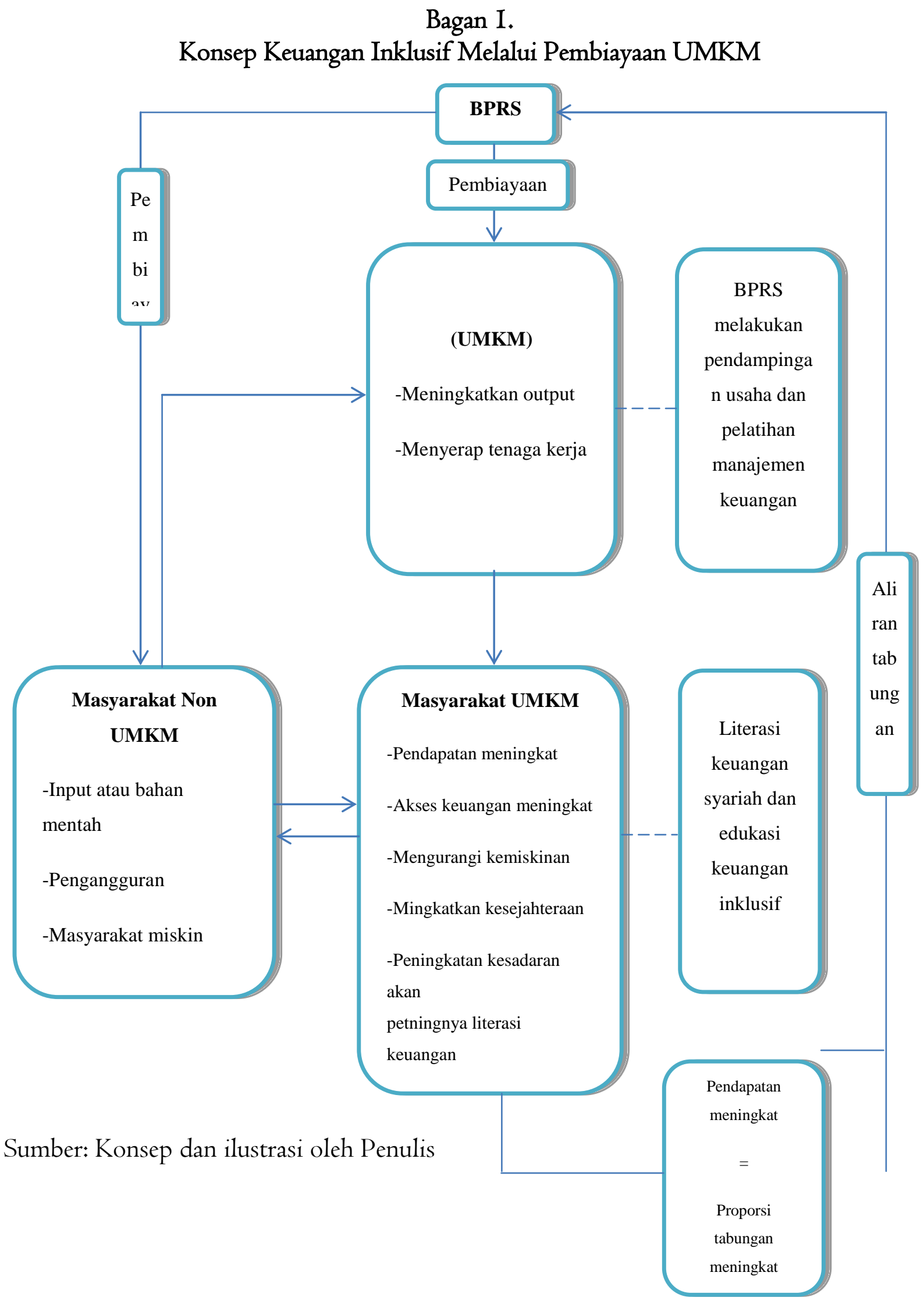

https:/ / journal.radenintan.ac.id/index.php/ikonomika

E-mail:ikonomika_submission@radenintan.ac.id 
Konsep yang digagas oleh penulis merupakan sebuah terobosan yang coba ditawarkan untuk mempercepat pengimplementasian keuangan inklusif di Indonesia melalui pembiayaan UMKM. Seperti yang sudah dipaparkan dalam penelitian ini bahwa UMKM memegang peran penting dalam perekonomian di Indonesia. Hal ini didasari oleh penyerapan tenaga kerja yang lebih banyak dan skala usaha yang tidak terlalu besar sehingga bisa dilakukan oleh berbagai lapisan masyarakat terutama kalangan menengah bawah. Terlibatnya banyak masyarakat melalui UMKM adalah salah satu pintu masuk BPRS untuk ikut berkontibursi memperdalam akses keuangan formal. Dalam konsep tersebut, BPRS yang memberikan bantuan pembiayaan kepada UMKM akan meningkatkan output dan skala usaha sehingga akan menyerap tenaga kerja lebih banyak yang kemudian masyarakat yang berkecimpung di UMKM akan meningkat pendapatannya dan kesejahteraanya dan tentu secara langsung akan mengurangi kemiskinan. Selain memberikan bantuan pembiayaan kepada UMKM, BPRS harus mendampingi jalannya usaha dan terlibat secara intens untuk memonitor untuk memastikan UMKM yang mendapat bantuan pembiayaan mampu mengelola keuangan dengan baik. Selain itu, dengan adanya masyarakat UMKM diharapkan dapat menjadi perpanjangan tangan dalam memperkenalkan dan mendidik masyarakat biasa (non UMKM) untuk ikut terlibat dalam kegiatan usaha yang mengikutsertakan lembaga keuangan formal. Biasanya, masyarakat biasa adalah mereka yang minim kreativitas sehingga tidak bisa mengelola sumber dayanya untuk memiliki value added. Disinilah peran masyarakat UMKM yang telah mendapat pelatihan dan edukasi keuangan untuk mensosialisasikan keapada masyarakat biasa tersebut. Bisa dalam bentuk membeli bahan mentah mereka untuk diolah menjadi barang bernilai jual dan atau melibatkan mereka sebagai tenagakerja kreatif. BPRS pun bisa masuk melalui masyarakat non UMKM terutama dalam bantuan pembiayaan bahan mentah (input) untuk diolah menjadi layak dipasarkan melalui UMKM. Artinya, masyarakat yang tadinya tidak berkecimpung dalam UMKM pada akhirnya akan menggeluti UMKM. Semakin banyaknya masyarakat UMKM tentu akan meningkatkan pendapatan mereka dan hal ini akan membuat proporsi tabungan mereka meningkat dan BPRS menjadi lembaga keuangan dimana mereka akan menabung uang tersebut. Bagaimanapun, akan terjadi lingkaran mutual benefit kegiatan yang semakin tinggi apabila konsep ini dapat berjalan dengan baik.

Penelitian ini tentu masih memerlukan tindak lanjut yang lebih dalam untuk membuktikan peran UMKM dalam berkontribusi pada implementasi keuangan inklusif. Bagaimanapun juga, penelitian yang dirancang saat ini menunjukkan 
IKONOMIKA

Volume 2, No 2 (2017)

indikator bahwa keuangan inklusif melalui BPRS terhadap pembiayaan UMKM adalah baik. Pada hakikatnya, indikator ini perlu diperluas apalagi pangsa pasar lembaga keuangan syariah masih belum sebesar perbankan konvensional. Paling tidak, dalam penelitian ini membuktikan bahwa BPRS selaku lemabaga keuangan syariah mampu terlibat secara luas dalam mengimplementasikan keuangan inklusif melalui data yang ada dimana secara konsisten fokus kepada sektor UMKM dalam hal pembiayaan dan lebih lanjut juga didukung dengan baiknya rasio keuangan yang ada pada BPRS.

\section{PUSTAKA ACUAN}

Allen, F., Demirguc-Kunt, A, Klapper, L, and Peria, M. 20I2. The

Foundations of Financial Inclusion: Understanding Ownership and Use of Formal Accounts. World Bank Policy

Paper 6290

Ascarya. 20I I. Akad dan Produk Bank Syariah. Jakarta. Rajawali Press.

Chakrabarty, Kamalesh Shailesh C. 20I2. Financial Inlcusion - Issues in Measurement and

Analysis. Irving Fisher Committee Workshop on Financial Inclusion Indicators. Malaysia.

Demigruc-Kunt, Asli et al. 20I4. Deposit Insurance Database. IMF Working Paper/I4/II8.

Dewandru, Janu. 2009. Apa yang Sebenarnya Ditawarkan Ekonomi Islam. Islam and

Contemporery Issues ed, Ahmad Syukri Shaleh dan Ahmad Syukri Bahrudin. Jambi. PPs IAIN Jambi

Ernst and Young. World Islamic Banking Competitiveness Report 20I320I4. Page 69.

Isretno, R.A. Evita. 20I I. Pembiayaan Mudharabah dalam Sistem Perbankan Syariah. Jakarta. Cyntia Press.

Karim, Adiwarman A. 20I I. Ekonomi Mikro Islam. Jakarta. Rajawali Press.

Keskin, Hidayat et al. 2010. The Importance of SMEs in Developing Economies. $2^{\text {nd }}$ International Symposium in Sustainable Development. Sarajevo

Leon, Florian and Laurent Weill. 20I7. Islamic Banking Development and Access to Credit. Pacific-Basin Finance Journal. Madanchian, Mitra et al. 2015. The Role of SMEs in Economic Development: Case Study of

Malaysia. International Journal of Academic Research in Management. Vol 4, No 3, Page $77-84$. 
Peran Bank Pembiayaan Rakyat Syariah dalam Mengimplementasikan Keuangan Inklusif Melalui Pembiayaan UMKM

(Achmad Rifa'i)

Moeloeng, Lexy J. 2004. Metode Penelitian Kualitatif. Badung. Remaja Rosdakarya.

Mohieldin, Mahmoud et al. 2012. The Role of Islamic Finance in Enhancing Financial

Inclusion in Organizations of Islamic Cooperation (OIC) Countries. Islamic Economic Studies. Vol 20, No 2, Page 55 - II 9.

Partomo, T.S dan Soejoedono A.R. 2004. Ekonomi Skala Kecil/Menengah dan Koperasi. Ghalia Indonesia. Jakarta.

Sabiq, Sayyid. 2009. Fiqih Sunnah Volume 5. Terjemahan oleh Abdurrahin dan Masrukhin. Jakarta. Cakrawala Publishing.

Strauss, A and Corbin, J. 2007. Basic of Qualitative Research: Techniques and Procedures for Developing Grounded Theory (3rd ed). Sage Publications.

Suryomurti, Wiku. 20I I. Peran Perbankan Syariah Dalam Pembiayaan Mikro.

Syed, Anwar Ali Shah G. et al. 20I2. Impact Analysis of SMEs Sector in Economic

Development of Pakistan: A Case of Sindh. Journal of Asian Business Strategy. Vol 2, No 2, Page $44-53$. 